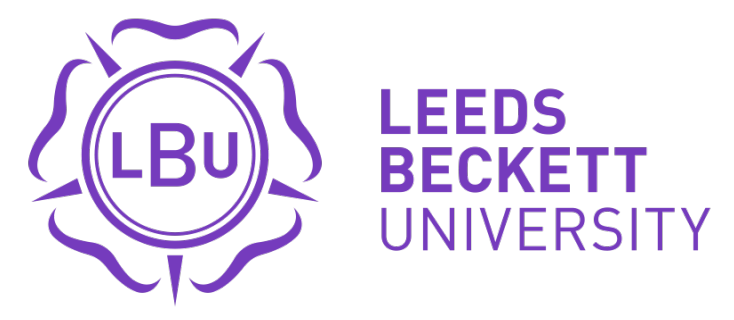

Citation:

Ramírez-López, $\mathrm{C}$ and Till, $\mathrm{K}$ and Boyd, $\mathrm{A}$ and Bennet, $\mathrm{M}$ and Piscione, $\mathrm{J}$ and Bradley, $\mathrm{S}$ and Giuliano, P and Leduc, C and Jones, B (2020) Coopetition: cooperation among competitors to enhance applied research and drive innovation in elite sport. British Journal of Sports Medicine. ISSN 0306-3674 DOI: https://doi.org/10.1136/bjsports-2020-102901

Link to Leeds Beckett Repository record:

https://eprints.leedsbeckett.ac.uk/id/eprint/6974/

Document Version:

Article (Accepted Version)

Creative Commons: Attribution-Noncommercial 4.0

The aim of the Leeds Beckett Repository is to provide open access to our research, as required by funder policies and permitted by publishers and copyright law.

The Leeds Beckett repository holds a wide range of publications, each of which has been checked for copyright and the relevant embargo period has been applied by the Research Services team.

We operate on a standard take-down policy. If you are the author or publisher of an output and you would like it removed from the repository, please contact us and we will investigate on a case-by-case basis.

Each thesis in the repository has been cleared where necessary by the author for third party copyright. If you would like a thesis to be removed from the repository or believe there is an issue with copyright, please contact us on openaccess@leedsbeckett.ac.uk and we will investigate on a case-by-case basis. 
Editorial

\section{Coopetition: cooperation among competitors to enhance applied research and drive innovation in elite sport}

Running head: Coopetition for enhancing applied research and innovation in elite sport

Carlos Ramírez-López1,2,3, Kevin Till1,4, Andy Boyd5, Mark Bennett6,7, Julien Pisciones, Sam Bradley9,10, Pierosario Giuliano11, Cedric Leduc1, Ben Jones1,3,11,12,13.

1Leeds Beckett University, Carnegie Applied Rugby Research (CARR) centre, Carnegie School of Sport, Leeds, United Kingdom 2Yorkshire Carnegie Rugby Union club, Leeds, United Kingdom 3England Performance Unit, The Rugby Football League, Leeds, United Kingdom 4Leeds Rhinos Rugby League club, Leeds, United Kingdom 5Scottish Rugby Union, Murrayfield Stadium, Edinburgh, United Kingdom 6Rugby Football Union, Twickenham Stadium, London, United Kingdom 7Rugby Union of Russia, Moscow, Russia 8French Rugby Federation, Centre National de Rugby, Marcoussis, France 9Welsh Rugby Union, Principality Stadium, Cardiff, United Kingdom 10English Institute of Sport, High Performance Centre, Manchester, United Kingdom 11Italian Rugby Federation, Stadio Olimpico, Rome, Italy 12School of Science and Technology, University of New England, Armidale, NSW, Australia 13 Division of Exercise Science and Sports Medicine, Department of Human Biology, Faculty of Health Sciences, the University of Cape Town and the Sports Science Institute of South Africa, Cape Town, South Africa 
Corresponding author: Carlos Ramírez-López

Room G08, Cavendish Hall

Carnegie School of Sport

Leeds Beckett University, Headingley Campus

LS6 3QS

United Kingdom

Phone: +44 7999554650

Email: c.ramirez@leedsbeckett.ac.uk

Word count: 785 words 


\section{INTRODUCTION}

The essence of competition is often understood as a situation of mutually exclusive goal attainment, where one side succeeds only if another does not. However, and as studied by the game theory, this standard view may be too narrow and simplistic when trying to understand complex interactions.[1] Researchers in business and management have expanded on this and explored cases of simultaneous cooperation and competition (i.e. coopetition) as the most complex but advantageous relationship among competitors and as an effective strategy to drive innovation.[2]

Scientific innovation can be crucial for maximising athletes' health and performance, which has resulted in a growing interest in sports science and medicine (SSM). Innovation through research helps develop training models, medical treatments and recovery methods[3] but the practical relevance of some fundamental studies is often hindered by their poor ecological validity. Tightly controlled conditions can create an artificial sample of athletes and circumstances which are not truly representative of daily practice, allowing for the gap between research and practice to persist. Applied research aims to bridge that gap by developing ecologically valid evidence and can be further enhanced by embedding 'off-field' academic brains into sporting organisations.[4] However, the quality of research outputs can be limited by small sample sizes and restricted access to resources and specialised instrumentation. Merging performance data from different teams has been suggested as a solution; however, practitioners from professional organisations may be reluctant to share such data and resources between them. In this editorial, we aim to (i) alert the sports medicine/science community to the concept of coopetition and its relevance to our field, and (ii) propose a conceptual framework for its use to enhance the methods and quality of applied research and drive innovation. 


\section{TO COOPERATE AND COMPETE SIMULTANEOUSLY?}

Relationships between rival companies have been long studied as a means of innovation[5] alongside the influence of coopetition on the strategic operations of the involved firms (e.g., research and development, innovation, product manufacturing).[2,5] Within coopetition, organisations can compete due to conflicting interests, and at the same time, cooperate due to a common interest in developing specific knowledge. Different cases of success have been reported in the business literature[2] (e.g. joint development of LCD panels between Sony and Samsung; joint development of eco-friendly vehicles between Toyota and General Motors), and it is conceivable then that practice of coopetition could be adopted by applied research in SSM. National squads or elite teams rival each other during competitions but often face similar challenges and share common goals (e.g. safe enhancement of athletic development, reduction in injury risk). However, to date, coopetition has received limited attention in SSM (e.g. [6,7]), although some cases exist in the field of sports management.[8] In SSM, the operational relationships among the contending sides have not yet been explored. To our knowledge, no conscious efforts have been made to propose a framework for enhancing applied research through coopetition in elite sport.

\section{COOPETITION MANAGEMENT, A FRAMEWORK AND THE THIRD-PARTY}

The coexistence of cooperation and competition can be a challenging situation as it involves sources of conflict due to the complex nature of the relationship. Thereby, the involvement of a third-party is required to carefully manage fructuous coopetition relationships, and we believe that an associated university would be the most suitable for that role. By doing so, organisations benefit from access to 'off-field brains', specialised instrumentation, operating systems, and the prospect to publish selected findings in scientific journals.[4] As illustrated in Figure 1, and adapted from an available nine-step applied research model,[4] the university would be 
expected to (1) mediate between the organisations to identify common challenges and develop appropriate co-constructed research questions; (2) seek ethical approval; (3) design and implement agreed standardised, valid and reliable data collection protocols; (4) pool, anonymise and analyse the collected data; (5) disseminate results back to the organisations without compromising anonymity; (6) write the relevant research paper(s); and (7) facilitate the integration of the newly acquired knowledge into practice. In this way, any risk of potential leaks of sensitive information between rivals is addressed, while the involved organisations are still able to benefit from the pooled data, the results and the subsequent new knowledge. Fundamentally, the third-party acts as a provider of academic expertise, a neutral authority in decision-making and as a trustee of sensitive information within the coopetition relationship.

\section{***PLEASE INSERT FIGURE 1 NEAR HERE***}

\section{SUMMARY}

Research in business and management has shown that the coexistence of cooperation and competition among companies can have a positive influence on the development of knowledge and success measures. The same principle may apply to the fields of SSM, where multiple factors restrict the quality of applied research outputs. The inclusion of a neutral third party (i.e. a university) into coopetition relationships would likely benefit all stakeholders.

\section{COMPETING INTERESTS}

None 
$\mathrm{CR}$ adapted the theory and developed the framework. KT, AB, MB, JP, SB, PG, CL and BJ made substantial contributions by discussing, challenging and further developing the original ideas. All authors critically revised the manuscript for important intellectual content.

\section{ACKNOWLEDGEMENTS}

The authors would like to thank the Rugby Football Union (RFU), French Rugby Federation (FFR), Italian Rugby Federation (FIR), Scottish Rugby Football Union (SRU) and Welsh Rugby Union (WRU) for allowing the necessary conditions for developing the framework presented in this editorial.

\section{FUNDING INFO}

No external funding was received 


\section{REFERENCES}

1 Leyton-Brown K, Shoham Y. Essentials of Game Theory: A Concise Multidisciplinary Introduction. Synth Lect Artif Intell Mach Learn 2008;2:1-88. doi:10.2200/S00108ED1V01Y200802AIM003

2 Bengtsson M, Kock S. "Coopetition" in Business Networks - to Cooperate and Compete Simultaneously. Ind Mark Manag 2000;29:411-26. doi:10.1016/S00198501(99)00067-X

3 Speed CA, Roberts WO. Innovation in high-performance sports medicine. Br J Sports Med 2011;45:949-51. doi:10.1136/bjsm.2010.075374

4 Jones B, Till K, Emmonds S, et al. Accessing off-field brains in sport; An applied research model to develop practice. Br J Sports Med 2019;53:791-3. doi:10.1136/bjsports-2016-097082

5 Ritala P, Hurmelinna-Laukkanen P. What's in it for me? Creating and appropriating value in innovation-related coopetition. Technovation 2009;29:819-28. doi:10.1016/j.technovation.2009.07.002

6 Carling C, Lacome M, Flanagan E, et al. Exposure time, running and skill-related performance in international $\mathrm{u} 20$ rugby union players during an intensified tournament. PLoS One 2017;12:1-15. doi:10.1371/journal.pone.0186874

7 Ramírez-López C, Till K, Sawczuk T, et al. A multi-nation examination of the fatigue and recovery time course during the inaugural Under-18 Six Nations rugby union competition. J Sports Sci 2020;38:644-51. doi:10.1080/02640414.2020.1722589

8 Robert F, Marques P, Le Roy F. Coopetition between SMEs: An empirical study of French professional football. Int J Entrep Small Bus 2009;8:23-43.

doi:10.1504/IJESB.2009.024103 


\section{FIGURE CAPTIONS}

Figure 1 Illustrated conceptual framework for sports science and medicine coopetition relationships between elite sporting organisations with the inclusion of a third party. 